\title{
Medicolegal
}

\section{Teenage confidence and consent}

\author{
BY OUR LEGAL CORRESPONDENT
}

Described by Lord Devlin in a letter to The Times' as a case "which may well be socially the most important to come before the courts in this decade," Gillick $v$ West Norfolk and Wisbech Area Health Authority and DHSS has been decided in favour of Mrs Gillick in the Court of Appeal ${ }^{2}$ and is set for further appeal to the House of Lords. ${ }^{3}$

The issue is whether the decision of joint heads of family on the treatment of their children can be either overruled or avoided by outsiders without the intervention of the courts. The Court of Appeal has decided that the rights and duties of parents are paramount unless overruled by the courts except in emergencies. The case also gives rise to important pronouncements on consent to treatment by young people.

Mrs Victoria Gillick, the mother of five daughters under the age of 16, was concerned by the terms of a Health Service Notice (HN (80) 46 ) issued by the DHSS in December 1980 . She wrote to the West Norfolk and Wisbech Area Health Authority asking for an assurance that none of her daughters would be given contraceptive or abortion treatment while they are under 16 without her prior knowledge and consent and also for an assurance that should any of her daughters seek advice in a family planning clinic she would automatically be contacted in the interests of her children's safety and welfare.

Not having received any assurance satisfactory to her, Mrs Gillick sued the area health authority and the DHSS claiming two declarations:

(1) That the health notice had no authority in law and gave advice which was unlawful and wrong and which did or might adversely affect the welfare of Mrs Gillick's children, her rights as a parent, and her ability effectively to discharge her duties as a parent; and

(2) That no doctor or other person employed by the health authority either in the family planning service or otherwise might give any contraceptive or abortion advice to any child of Mrs Gillick under the age of 16 without the prior knowledge and consent of the child's parent or guardian.

The judge at first instance refused any relief to Mrs Gillick. ${ }^{+}$The Court of Appeal, however, granted both declarations but qualified the second declaration by the addition of the important words, "save in cases of emergency or with leave of the court."

The Court of Appeal also gave leave to appeal to the House of Lords. Mr Kenneth Clarke, Minister of State for Health, has announced the intention of the DHSS to appeal.

\section{Legal aid}

The award of legal aid to Mrs Gillick for her action has caused resentment in some quarters, though one would have thought that there would have been general satisfaction that a public debate of this importance should be funded on both sides by public funds. The important issues deserve the further debate which they will receive in the House of Lords, unmarred by the personal invective and intolerance which has sadly marked much of the comment outside the courts. Meanwhile the Court of Appeal's ruling is the latest statement of the law and cannot be treated as being in suspense pending the outcome of the further appeal.
Giving the leading judgment in the Court of Appeal, Lord Justice Parker said that it was clear that respectable and responsible people might hold strong views as to the moral, religious, or ethical issues arising out of the case. The court was concerned, however, only with the legal position, though in the course of ascertaining it the court might resort to established public policy which might itself be based on some social, moral, or other non-legal judgment.

The case was presented in two parts: firstly, the question of the extent of a parent's rights and duties regarding medical treatment of a girl under 16, and, secondly, the extent to which, if at all, the provision of the criminal law assisted in the determination of those rights and duties. The Court of Appeal placed somewhat less emphasis on the criminal law than did Mr Justice Woolf.

\section{Parent's rights and duties}

Lord Justice Parker referred to three statutory provisions in relation to a parent's rights and duties in relation to children. The Family Law Reform Act 1969 had reduced the age of majority from 21 to 18 and by section 8 provided that the consent of a minor aged 16 or over to surgical, medical, or dental treatment was as effective as if the minor was of full age. Sections 85 and 86 of the Children Act 1975 appeared to recognise that the parents of a child have both rights and duties in respect of a child which they could not opt out of and defined "legal custody" as "so much of the parental rights and duties as relate to the person of the child (including the place and manner in which his time is spent ...)." Section 48 of the Education Act 1944 recognised the right of a parent to control the treatment provided at schools for any child up to the age of 19.

Lord Justice Parker held that these three statutes supported Mrs Gillick's case. If there was a right and duty to determine the place and manner in which a child's time was spent, such right or duty must cover the right and duty completely to control the child, subject always to the intervention of the court.

Lord Justice Parker might have referred to other statutes. For example, the Marriage Act 1949 as amended requires a parent's consent for the marriage of a person under the age of 18 , subject to the overriding decision of the court. Is a parent who has a veto over marriage to be deprived of a persuasive voice in the matter of sexual intercourse? Moreover, the Tattooing of Minors Act 1969 makes it an offence to tattoo a person under the age of 18 unless the tattoo is done for medical reasons by a qualified medical practitioner. Does this not indicate the view of our legislators as to the ability of our children under 18 to take responsible decisions for themselves?

Having concluded that a parent has a right and duty completely to control the child, Lord Justice Parker went on to consider whether this right and duty existed to a fixed age or whether its duration depended on the maturity and understanding of the child in question. The Lord Justice concluded that the right and duty existed up to a fixed age-namely, the age of majority, 18. Clearly the alternative position would undermine the control exercised by the court, since anyone might claim to form a view that a particular individual had sufficient maturity to make important decisions at some age before 18 .

In emphasising that the age of majority prevailed Lord Justice 
Parker recognised that there are exceptions provided by statute or on marriage or on joining the armed forces.

\section{Doctor's liability}

The Lord Justice then turned to the question of the potential criminal liability of a doctor providing contraceptive advice and treatment to a girl under 16. After a review of the statutory history Lord Justice Parker pointed out that section 14 of the Sexual Offences Act 1956 provided that no girl under 16 could in law give consent so as to prevent an act being an indecent assault under the section. In the view of the Lord Justice a doctor who, for example, made a vaginal examination of a 10 year old as a preliminary to contraceptive advice and treatment was at least at risk of prosecution for indecent assault unless he had the consent of a parent, and that was so up to the age of 16 , when, if the child consented, the consent was valid by statute and there was no offence. Moreover, it had always been the law that for a plain civil trespass to a child a parent had his own right to sue in certain circumstances.

In the final analysis it was Lord Justice Parker's view that it was clearly established that a parent or guardian had, as such, a parcel of rights in relation to children in his custody. By statute, such rights could in general be neither abandoned nor transferred.

Such rights included the right to control the manner in which and the place at which the child spent his time. Those rights would be enforced by the court subject to the right of the court to override the parental rights in the interests of the child.

\section{Resort to courts}

There was no authority of any kind to suggest that anyone other than the court could interfere with the parents' rights otherwise than by resort to the courts or pursuant to specific statutory powers or exceptions.

In the view of the Lord Justice a girl under 16 could neither by her consent deprive any assault of its criminal nature nor validly prohibit a doctor from seeking parental consent. Moreover, any doctor who advised a girl under 16 as to contraceptive steps to be taken or afforded contraceptive advice or abortion treatment to such a girl without the knowledge and consent of her parents, save in emergency, infringed the legal rights of her parent or guardian. Except in cases of emergency, the proper course was to seek the parents' consent or apply to the court. The other two members of the Court of Appeal delivered concurring judgments.

\section{Wider implications}

The decision is not limited in its effect to contraceptive advice and treatment of young girls. The implications of the decision extend to all medical treatment of all young people, boys and girls. The Court of Appeal firmly favours the view that the wishes of parents are paramount unless the court overrules them and that the parents must be asked to express their consent or dissent. Clearly in some cases doctors will form the view that the parents have forfeited any right to be consulted. But while doctors are entitled to form such a view they have no right in law to act upon such a view. If they do so they will arrogate to themselves the entitlement to affect other peoples' rights. Doctors have no right in law to follow such a course, and if they do go along that road they will attract the odium that falls on those who seek to control the lives of the people without their consent.

Moreover, it is worth remembering that to make the wishes of the child or teenage patient paramount may in some cases deprive that patient of desirable treatment. Suppose a 17 year old boy-for reasons of religion not shared by his parents-refused exploratory surgery for a condition which clearly required it, would the doctor not insist on speaking to his parents about it to enlist their aid in persuading him to accept treatment? And if the 17 year old is to be treated as sufficiently mature to take a foolish decision about his health without his parents being involved, what is the youngest age at which a child is to be treated in the same way? If all doctors were superhuman in their maturity of judgment no doubt the decision could be left with each individual doctor, but few doctors would be happy to allow their own children to decide their own treatment with the doctor of their own choice without parental intervention.

Nevertheless the position is further complicated by the court's various rulings as to ages: the parents' rights and duties exist until the child is 18; a girl under the age of 16 can give no valid consent in civil or criminal law in the relevant areas; for boys the age of 14 was mentioned, but that was in relation to authorities on habeas corpus and it must be doubtful whether it was intended to suggest that boys can validly consent to treatment at a younger age than girls. In the example of the 17 year old boy given above, he plainly can consent to treatment (the Family Law Reform Act 1969 says so). If he unreasonably refused to consent his parents would have rights and duties to seek to persuade him if they knew about the problem but it is doubtful whether the doctor would have any duty in law to tell them about it. But a 15 year old boy would have no statutory right to consent and it is very doubtful that he has any such right at common law despite the reference to the habeas corpus authorities. The better view would appear to be that the age of consent to treatment for both boys and girls is 16 and that as a result of this decision no treatment of any sort should be given to a child under the age of 16 without consent of the parents save in emergency or with leave of the court. When a child under the age of 16 consults a doctor without the parents' knowledge and refuses treatment where clearly treatment is required the doctor is probably under a legal duty to inform the parents so that they can perform their duties in the matter.

\section{Emergency}

One of the practical problems which clearly will vex practitioners will be the interpretation of the words "save in emergency" inserted into the second declaration. What emergency will justify giving medical treatment to a minor without consent of the parent or guardian or the leave of the court? It is the tradition of common law courts to leave undefined areas at the edges of their decisions so that the law is not put into a straitjacket, unable to adapt to unforeseen circumstances. In the long run this is desirable, but difficulties arise in the short term.

The Court of Appeal gave no guidance on the meaning of "emergency," but perhaps one example might be suggested. Suppose a 15 year old girl comes to her general practitioner's Friday evening surgery with a story that she has been thrown out of her home by her parents and intends to join her boyfriend that evening in a squat. If her story is verified and she cannot be persuaded into alternative possibilities of more suitable accommodation it might be that there would be an emergency requirement of contraceptive advice and treatment over the weekend until application could be made to the court in "care" on wardship proceedings. Clearly the Court of Appeal had in mind that an emergency only existed during the time taken to filing an application before the court, and normally in urgent cases concerning the welfare of children that should be only a matter of days. This is one of the many areas where medicine shades into social work and the support team of the general practice comes into play.

\section{References}

1 Lord Devlin. Social importance of pill ruling. The Times 1983 July $29: 9$ (col 4)

2 Anonymous. DHSS contraceptive notice is unlawful [Editorial]. The Times $1984 \mathrm{Dec} 21: 9$ (cols Anonym

3 Nicholson-Lord D. Appeal to Lords on pill ruling. The Times 1984 Dec 28:1 (cols 4-7), 28 (cols 3-5). 4 [1983) 3 WLR 859 